\title{
Reduction of sleeping metabolic rate after vertical banded gastroplasty.
}

Citation for published version (APA):

van Gemert, W. G., Westerterp, K. R., Greve, J. W. M., \& Soeters, P. B. (1998). Reduction of sleeping metabolic rate after vertical banded gastroplasty. International Journal of Obesity, 22(4), 343-348. https://doi.org/10.1038/sj.ijo.0800592

Document status and date:

Published: 01/01/1998

DOI:

10.1038/sj.ijo.0800592

Document Version:

Publisher's PDF, also known as Version of record

Document license:

Taverne

Please check the document version of this publication:

- A submitted manuscript is the version of the article upon submission and before peer-review. There can be important differences between the submitted version and the official published version of record.

People interested in the research are advised to contact the author for the final version of the publication, or visit the DOI to the publisher's website.

- The final author version and the galley proof are versions of the publication after peer review.

- The final published version features the final layout of the paper including the volume, issue and page numbers.

Link to publication

\footnotetext{
General rights rights.

- You may freely distribute the URL identifying the publication in the public portal. please follow below link for the End User Agreement:

www.umlib.nl/taverne-license

Take down policy

If you believe that this document breaches copyright please contact us at:

repository@maastrichtuniversity.nl

providing details and we will investigate your claim.
}

Copyright and moral rights for the publications made accessible in the public portal are retained by the authors and/or other copyright owners and it is a condition of accessing publications that users recognise and abide by the legal requirements associated with these

- Users may download and print one copy of any publication from the public portal for the purpose of private study or research.

- You may not further distribute the material or use it for any profit-making activity or commercial gain

If the publication is distributed under the terms of Article $25 \mathrm{fa}$ of the Dutch Copyright Act, indicated by the "Taverne" license above, 


\title{
Reduction of sleeping metabolic rate after vertical banded gastroplasty
}

\author{
WG van Gemert ${ }^{1}$, KR Westerterp ${ }^{2}$, JWM Greve ${ }^{1}$ and PB Soeters \\ Department of ${ }^{1}$ Surgery and ${ }^{2}$ Human Biology of the University Hospital Maastricht, The Netherlands
}

\begin{abstract}
OBJECTIVE: To investigate whether long-term weight loss after vertical banded gastroplasty (VBG) results in a sustained reduction of sleeping metabolic rate (SMR) as a persistent risk factor for weight regain.

DESIGN: Longitudinal clinical intervention study of morbidly obese patients undergoing VBG.

PATIENTS: Group I: Six patients in which body composition and SMR were measured before and at 3, 6 and 12 months after VBG. Group II (long-term effect): nine patients in which body mass (BM) was measured before VBG, and body composition and SMR were measured $98 \pm 30$ months after VBG.

MEASUREMENTS: Body composition was assessed by deuterium dilution and hydrostatic weighing. SMR was measured (SMRm) in a respiration chamber and predicted (SMRp) based on body composition.

RESULTS: In group $I$, fat mass and fat free mass decreased significantly after VBG $(P<0.05)$. SMRm decreased from $11.1 \pm 1.8$ (s.d.) $\mathrm{MJ} / \mathrm{d}$ before VBG to $8.1 \pm 0.9 \mathrm{MJ} / \mathrm{d}(P<0.05)$ at 12 months after VBG. In group II at a mean of $98 \mathrm{months}$ after VBG, the SMRm $(6.9 \pm 0.7 \mathrm{MJ} / \mathrm{d})$ was lower than the preoperative value of group I $(P<0.05)$. SMRm was lower than SMRp at all intervals after VBG $(P<0.05)$. The ratio measured vs predicted SMR was in group I: $1.02 \pm 0.05$ before VBG, $0.91 \pm 0.08$ at 12 months after VBG $(P<0.05)$, and in group II: $0.94 \pm 0.08$ at a mean of 98 months after VBG $(P<0.05)$.

CONCLUSION: The reduction of SMR adjusted for body composition after VBG is sustained as long as weight loss is maintained. The sustained and disproportional reduction of SMR may reflect the persistent susceptibility of the postobese to weight regain.
\end{abstract}

Keywords: morbid obesity; vertical banded gastroplasty; energy expenditure; sleeping metabolic rate; body composition

\section{Introduction}

There is accumulating evidence for a low habitual energy expenditure as a risk factor for obesity. ${ }^{1}$ The most important determinant of total energy expenditure is resting energy expenditure, which is mainly determined by body size and composition. There remains considerable interindividual variation in resting metabolic rate (RMR), even when controlled for body size and composition, which is in part genetically determined. ${ }^{2}$ Keesey $^{3}$ hypothesized that morbidly obese subjects strive to maintain a predetermined body weight and that weight loss is counteracted by a disproportional reduction of energy expenditure. This would explain the persistent propensity to overweight and weight regain after weight loss. This hypothesis is supported by the clinical observation that morbidly obese patients who reach and maintain ideal body weight for several years following surgical treatment return rapidly to their morbidly obese status when unlimited eating capacity is regained as a result of a technical failure.

Correspondence: Wim G. van Gemert, MD, Department of Surgery, University Hospital Maastricht, PO Box 5800, 6202 AZ Maastricht, The Netherlands.

Received 20 August 1997; revised 24 November 1997; accepted 9 December 1997
Kleiber ${ }^{4}$ demonstrated a logarithmic relationship between body weight and resting metabolic rate for many different animal species. By means of this relationship the RMR can be predicted. However, this relationship holds only when the subject is at its normally maintained physiological body weight. After weight loss, the measured energy expenditure will be lower than the predicted energy expenditure because the weight loss is counteracted by a disproportional decrease in energy expenditure. The normally maintained and defended physiological body weight of morbidly obese persons may be preset at a higher level. It would explain why conservative treatment does not achieve long-term weight loss and is associated with high initial failure rates or recidivism. ${ }^{5}$ Garrow $^{6}$ demonstrated that the decrease in metabolic rate is more than could be accounted for by the loss of lean tissue mass, and furthermore, that the energy equivalent of the body weight lost is affected by the rate of weight loss. At high rates of weight loss, the body weight lost is composed of a mixture of adipose tissue and lean tissue, while at low rates of weight loss, the body weight lost consists almost completely of adipose tissue. ${ }^{6}$

The results of studies regarding the role of energy expenditure in the pathogenesis of obesity are conflicting. ${ }^{7}$ The majority of these studies did include morbidly obese subjects and investigated energy 
expenditure over a short time after moderate dietaryinduced weight loss. In the present study, a surgical study model was preferred in which morbidly obese patients undergo surgical treatment. Surgical treatment generally results in a substantial and long-lasting weight $\operatorname{loss}^{8}$ and, consequently, larger changes in resting energy expenditure are expected and long term effects can be studied. To study the effect of weight loss on energy expenditure in a surgical study model, it is important to perform a restrictive surgical procedure, such as a vertical banded gastroplasty (VBG), where weight loss is purely the result of a restricted intake.

The hypothesis tested in this study, was that long-term weight loss after VBG results in a sustained and disproportionate reduction of sleeping metabolic rate (SMR) as a persistent risk factor for weight regain.

\section{Patients and methods}

\section{Patients}

Two series of patients were included in the analysis. Group I consisted of six patients measured before VBG and 3, 6 and 12 months after VBG in a prospective manner. A second group of patients several years after VBG was studied to investigate whether the results of the first study could be confirmed after sustained (long-term) weight reduction. Initially, group II consisted of 10 patients measured once, more than 36 months after VBG and with $>40 \%$ excess weight loss. Preoperatively, only the body mass (BM) was measured in the latter group. One patient from group II was excluded from the study, because this patient developed a septic episode during the study period, as a result of an enterocutaneous fistula after correction of an incisional hernia.

The study protocol and the equipment used were identical for both groups. All patients gave their written informed consent before participation in the study.

\section{Body composition measurements}

Body composition was assessed by deuterium oxide dilution and hydrostatic weighing. The patients drank the deuterium oxide solution at $23.00 \mathrm{~h}$ after collection of a baseline urine sample. The deuterium oxide dilution was measured in the urine sample of the second voiding in the morning, resulting in an equilibration time of $9-10 \mathrm{~h}$. The dose of deuterium oxide solution $\left(99.8 \%{ }^{2} \mathrm{H}_{2} \mathrm{O}\right)$ was approximately $0.1 \mathrm{~g}^{2} \mathrm{H}_{2} \mathrm{O} / \mathrm{kg}$ body water resulting in an excess enrichment of $100 \mathrm{ppm}$. Total body water before administration was estimated from age- and gender-specific formulae. ${ }^{9}$ Isotope abundance in the urine samples was measured with an isotope ratio mass spectrometer (VG Isogas, Aqua Sira, Cheshire,
UK). Total body water was calculated as the deuterium dilution space divided by 1.04 for correction of a $4 \%$ over-estimation of the dilution space. ${ }^{10}$

Whole body density was determined by hydrostatic weighing. Total $\mathrm{BM}$ and underwater weight were measured to the nearest $0.05 \mathrm{~kg}$ on a digital scale (Mettler, 240C, Greifensee, Switzerland). Simultaneously, residual lung volume was measured by the Helium dilution tech-nique (Mijnhardt Volugraph, Breda, The Netherlands).

A three body-compartment model was used to calculate fat mass (FM) and fat free mass (FFM) from BM, water mass and body volume. ${ }^{11}$

\section{Energy expenditure measurement}

SMR was measured in a respiration chamber. The patients were instructed to maintain their normal diet for at least 3 days prior to the experiment. SMR was measured during an overnight stay $(20.00-07.30 \mathrm{~h})$ in a respiration chamber. The subjects were not allowed to eat in the chamber and coffee or tea were allowed until $22.00 \mathrm{~h}$. SMR was measured over a period of three consecutive hours during minimal activity level as judged from Doppler radar observation. In the respiration chamber, the oxygen and carbon dioxide concentrations of the ingoing and outgoing air were measured with a paramagnetic analyser (Magnos 6G, Hartman \& Braun, Frankfurt, Germany) and an infrared analyser (URAS 3G, Hartman \& Braun, Frankfurt, Germany), respectively. ${ }^{12}$ Energy expenditure was calculated using Weir's formula. ${ }^{\text {3 }}$

SMR, as measured in the respiration chamber (SMRm), was compared with a predicted value (SMRp) based on FFM and FM using a regression formula: $\mathrm{SMRp}=0.85+0.102 \mathrm{FFM}+0.024 \mathrm{FM} .{ }^{14}$ Westerterp et al ${ }^{14}$ combined the data of 11 studies containing a total of 290 healthy subjects with a wide range of body weights $(38-215 \mathrm{~kg})$ in a multiple regression analysis to predict basal metabolic rate (BMR). ${ }^{14}$ BMR was calculated from FFM and FM. In the present study, the regression formula developed to predict BMR turned out to predict SMR very well. A regression formula to predict SMR based on the preoperative data of group I is practically the same as the regression formula developed by Westerterp et $a l .{ }^{14}$ The latter regression formula was chosen for the present study since it is better validated.

\section{Statistics}

$\mathrm{BM}, \mathrm{FFM}$ and FM $(\mathrm{kg})$ and SMR $(\mathrm{MJ} / \mathrm{d})$ are expressed as the mean value \pm s.d. Data were analyzed using the Statistical Package for Social Science (SPSS release 6.0, SPSS Inc, Chicago). ${ }^{15}$ Differences within the group were tested with the Wilcoxon Signed Ranks test and differences between groups with the Mann-Whitney U test. Statistical significance was considered present at $P<0.05$. 
Table 1 Preoperative characteristics of group I and II (mean \pm s.d.).

\begin{tabular}{lcc}
\hline & Group I & Group II \\
\hline$n$ & 6 & 9 \\
Age & $28 \pm 7$ & $32 \pm 5$ \\
Male:female & $5: 1$ & $3: 7$ \\
BM $(\mathrm{kg})$ & $155.5 \pm 31.1$ & $131.1 \pm 17.0$ \\
BMI $\left(\mathrm{kg} / \mathrm{m}^{2}\right)$ & $48.1 \pm 7.0$ & $45.7 \pm 5.7$
\end{tabular}

Group I consists of six patients measured in a prospective manner after vertical banded gastroplasty (VBG). Group II (long-term effect) consists of nine patients measured once, $98 \pm 30$ months after VBG and with $57 \pm 13 \%$ excess weight loss. The only significant difference between groups is the male: female ratio $(P<0.05)$. $\mathrm{BM}=$ body mass, $\mathrm{BMI}=$ body mass index.

\section{Results}

\section{Patients}

The preoperative characteristics of group I and II were comparable, except for the male : female ratio (Table 1). The mean period after surgical treatment was $98 \pm 30$ months $(40-150$ months) for the patients of group II and the mean percentage excess weight loss was $57 \pm 13 \%$. The body weight curve after VBG of both groups shows a rapid weight loss in the first 6 months and a slow weight loss from 6-12 months. At 12 months after VBG, stable body weight was achieved in both groups (Figure 1).

\section{Body composition}

The mean BM, FFM and FM of group I were significantly reduced after VBG $(P<0.05)$ (Table $2)$. The mean body weight lost at one year after VBG was $53.2 \pm 16.0 \mathrm{~kg}$ and consisted of $83 \pm 41 \%$ FM and $17 \pm 15 \%$ FFM. During rapid weight loss in the first six months after VBG, the mean body weight lost was $48 \pm 11 \mathrm{~kg}$ and consisted of $78 \pm 27 \% \mathrm{FM}$ and $22 \pm 14 \%$ FFM. From 6-12 months after VBG, the body weight lost was only $5 \pm 12 \mathrm{~kg}$ and was entirely composed of FM. In the latter period, the FFM showed a slight recovery.

The mean BM of group II was also significantly reduced after VBG $(131 \pm 17$ vs $93 \pm 11 ; P<0.01)$.

\section{Energy expenditure}

The mean SMRm of group I was significantly reduced at all intervals after VBG compared to the preoperative value $(P<0.05)$ (Table 3$)$. Before VBG the mean SMRm of group I was not different from the mean SMRp resulting in a SMRm/p ratio of $1.02 \pm 0.05$. At three and six months after VBG, during rapid weight loss, the mean SMRm of group I was significantly reduced compared to the mean SMRp $(P<0.05)$ and remained so in the weight-stable post-obese situation at 12 months after VBG $(P<0.05)$ (Figure 2$)$. Consequently, the $\mathrm{SMRm} / \mathrm{p}$ ratio dropped below 1.0 at three and six months after $\mathrm{VBG}$, during rapid weight loss, and remained lower than 1.0 in the weight-stable post-obese situation at 12 months after VBG in group I $(P<0.05)$ (Figure 3$)$.

The results of the prospective measurements of group I could be confirmed in group II, in which the long-term effects of sustained weight loss on SMR were studied. In group II the mean SMRm was lower than the mean SMRp $(P<0.05)$, and also lower than the preoperative mean SMRm of group I $(P<0.01)$. The SMRm/p ratio of group II was significantly lower than the preoperative $\mathrm{SMRm} / \mathrm{p}$ ratio of group I $(P<0.05)$.

\section{Discussion}

In the present study, the measured SMR was equal to the predicted SMR in the weight-stable obese situation, in which the patients were apparently at their

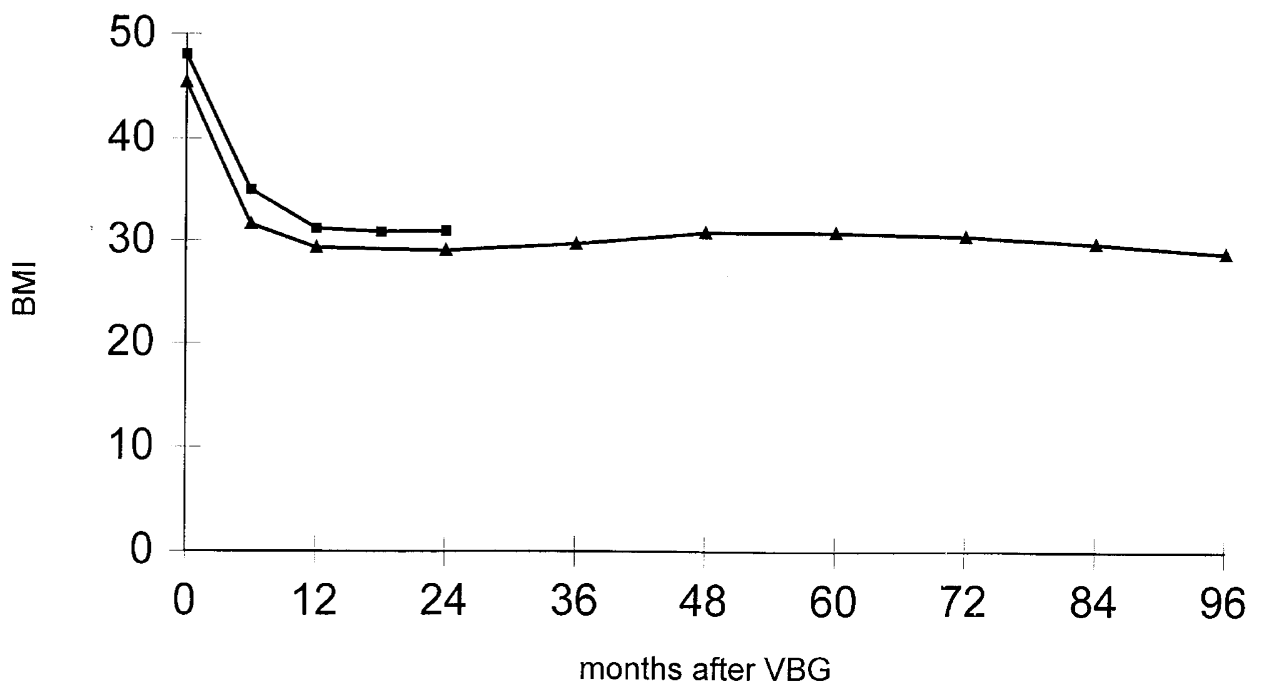

Figure 1 Body weight curve after vertical banded gastroplasty (VBG). The body weight curve expressed as body mass index (BMI $\left.\left(\mathrm{kg} / \mathrm{m}^{2}\right)\right)$ exhibits a rapid weight loss in the first six months after VBG. From 6-12 months after VBG, little body weight is lost and stable body weight is achieved at 12 months after VBG. The squares represent group I and the triangles represent group II. 
Table 2 Body composition at different intervals after vertical banded gastroplasty (VBG) (mean \pm s.d.).

\begin{tabular}{lrrrrr}
\hline & \multicolumn{3}{c}{ Group I } & & Group II \\
\cline { 2 - 5 } \cline { 3 - 5 } & Omonths & 3 months & 6 months & 12 months & $>36$ months \\
\hline BM (kg) & $155.5 \pm 31.1$ & $123.2 \pm 28.2^{*}$ & $107.4 \pm 25.9^{*}$ & $102.3 \pm 24.1^{*}$ & $93.2 \pm 10.5^{* *}$ \\
FM (kg) & $74.0 \pm 28.6$ & $49.2 \pm 22.3^{*}$ & $36.6 \pm 17.0^{*}$ & $30.0 \pm 11.4^{*}$ & $39.0 \pm 8.2^{* *}$ \\
FFM (kg) & $81.5 \pm 13.6$ & $73.9 \pm 13.7^{*}$ & $70.8 \pm 13.6^{*}$ & $72.3 \pm 13.0^{*}$ & $54.2 \pm 7.2^{* *}$
\end{tabular}

Group I consists of six patients measured in a prospective manner after VBG. Group II (long-term effect) consists of nine patients measured once, $98 \pm 30$ months after VBG and with $57 \pm 13 \%$ excess weight loss. $\mathrm{BM}=$ body mass, $\mathrm{FM}=$ fat mass, $\mathrm{FFM}=$ fat free mass. ${ }^{*} P<0.05,{ }^{* *} P<0.01$ for differences with the preoperative values of group I (differences within group I are tested with the Wilcoxon Signed Ranks test and between group I and II with the Mann-Withney U Test).

Table 3 Measured (SMRm) and predicted sleeping metabolic rate (SMRp) at different intervals after vertical banded gastroplasty (VBG) (mean \pm SD)

\begin{tabular}{lccccc}
\hline & \multicolumn{3}{c}{ Group I } & Group II \\
\cline { 2 - 5 } & Omonths & 3 months & 6 months & 12 months & $>36$ months \\
\hline SMRm & $11.1 \pm 1.8$ & $8.4 \pm 1.6^{*}$ & $7.9 \pm 1.6^{*}$ & $8.1 \pm 0.9^{*}$ & $6.9 \pm 0.7^{* *}$ \\
SMRp & $10.9 \pm 1.5$ & $9.6 \pm 1.6^{*}$ & $9.0 \pm 1.6^{*}$ & & $9.0 \pm 1.6^{*}$ \\
& $7.3 \pm 0.8^{* *}$ & & $1.02 \pm 0.05$ & $0.88 \pm 0.06^{*}$ & $0.88 \pm 0.04^{*}$ \\
& & & & & \\
\hline
\end{tabular}

Group I consists of six patients measured in a prospective manner after VBG. Group II (long-term effect) consists of nine patients measured once, $98 \pm 30$ months after VBG and with $57 \pm 13 \%$ excess weight loss. SMRm/p = ratio measured $v s$ predicted energy expenditure. ${ }^{*} P<0.05,{ }^{* *} P<0.01$ for differences with the preoperative values of group I (differences within group I are tested with the Wilcoxon Signed Ranks test and between group I and II with the Mann-Withney U Test).

a

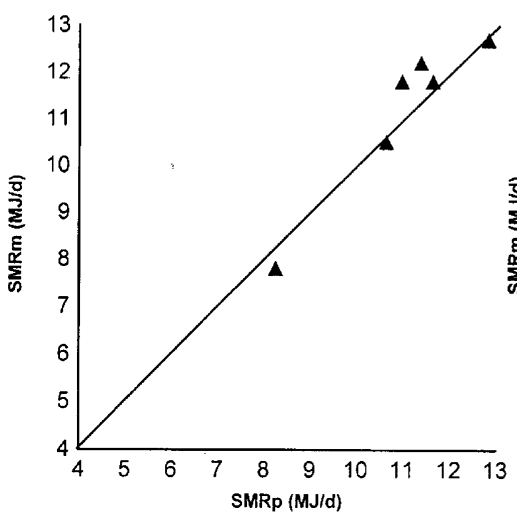

b

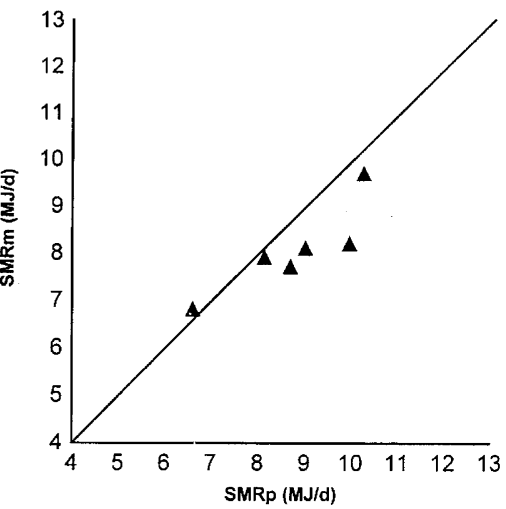

C

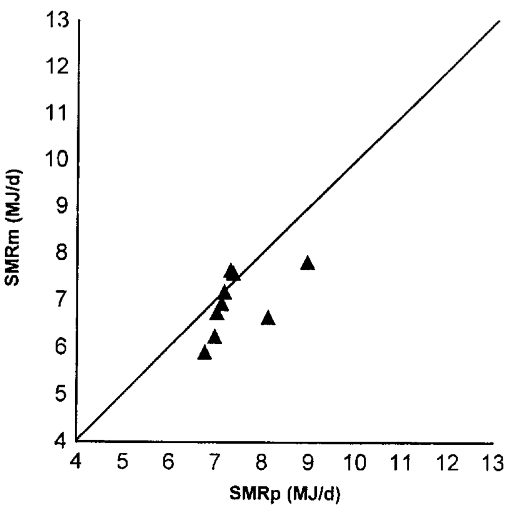

Figure 2 Measured (SMRm) and predicted (SMRp) sleeping metabolic rate in the weight-stable situations. These figures show the individual values of SMRm and SMRp in the weight-stable situations: group I before vertical banded gastroplasty (VBG) (a), group I at 12 months after VBG (b) and group II $>3 y$ after VBG (c). The individual values of group I before VBG are distributed around the reference line $S M R m / p=1$, while 12 months after VBG in group I and in group II the individual values are distributed below the reference line.

predetermined physiological body weight. As soon as weight loss occurs, the measured SMR drops below the predicted SMR. At three and six months after VBG, the reduction of SMR is at least partially explained by a prevailing negative energy balance, since the patients were still losing weight. However, a long-term stable weight reduction after VBG, results in a measured SMR which is still significantly lower than the predicted SMR, implying that the disproportionate reduction of SMR is sustained as long as weight loss is maintained.
Reports in the literature are conflicting regarding the effect of weight loss on the disproportionate reduction in energy expenditure. Although many studies showed a reduced energy expenditure disproportional to weight $\operatorname{loss}^{16-26}$, other studies could not confirm these results. ${ }^{27-34}$ Most of the studies in which the subjects are used as their own controls, show a reduction of RMR larger than expected, based on body composition. ${ }^{16,17,19,21-23}$ In contrast, the majority of studies comparing stable post-obese subjects with weight-matched controls, did not yield a 


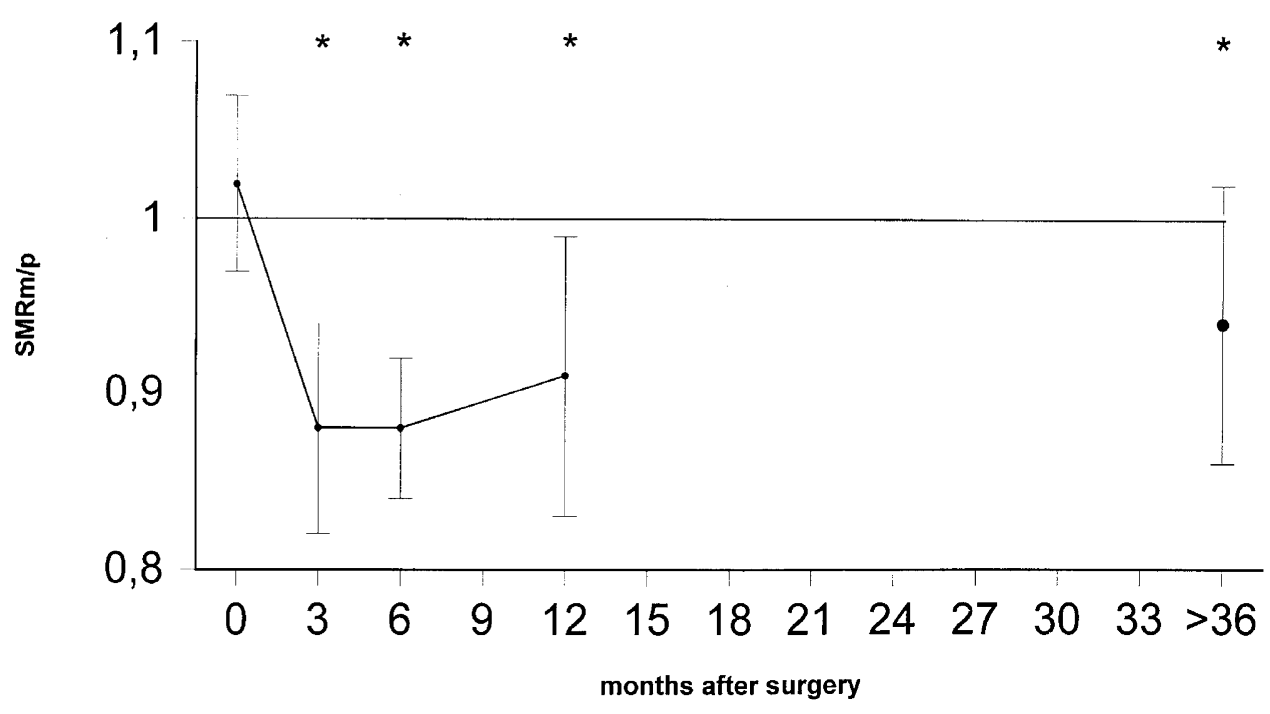

Figure 3 The ratio's measured $v s$ predicted sleeping metabolic rate (SMRm/p) of group I and group II. The SMRm/p of group I before vertical banded gastroplasty (VBG) is approximately one. At 3,6 and 12 months after VBG the SMRm/p ratio of group I drops below one (closed circles). The SMRm/p ratio of group II $>3 y$ after VBG is also below one (open circle). The error bars represent the s.d. ${ }^{*} P<0.05$ for differences with the preoperative value of group I (differences within group I are tested with the Wilcoxon Signed Ranks test and between group I and II with the Mann-Withney U Test).

disproportionate reduction in $\mathrm{RMR}^{27-30,32}$ The latter studies had in common that the study population was recruited by advertisement and some of these studies had a high drop out rate, which introduces a selection bias.

Furthermore, most of these studies have a small sample size which creates the risk that an actual difference may be overlooked. An overview of 11 studies comparing post-obese with matched controls, revealed a subnormal resting energy expenditure for a given body composition in all studies, however, the differences were significant in only three studies. ${ }^{35}$ Because the difference in resting energy expenditure is only $4-5 \%$, the sample sizes of these studies were not large enough to detect this difference consistently. A pooled analysis of these 11 studies by Astrup $^{35}$ provided a larger sample size, and the 4-5\% difference in resting energy expenditure became significant.

In the present study, the SMR was adjusted for body composition by using the ratio of measured $v s$ predicted SMR, in which the predicted SMR incorporates FFM as well as FM. The way in which RMR is expressed is important, since it can change the conclusions drawn. Heshka et $a l^{17}$ measured RMR and FFM in 35 obese subjects enrolled in a conservative weight loss program. The RMR-FFM ratio did not change with weight loss. However, regression analysis showed that the RMR declined to a greater degree than the FFM alone. The additional decline correlated significantly with the loss of FM. Hoffmans et al ${ }^{36}$ reported a significant contribution of FM to the explained variance in SMR or RMR in normal and moderately obese subjects. In most studies RMR is expressed per unit FFM, without correction for FM, resulting in an overestimation of measured RMR, since FM contributes significantly to RMR. This error becomes more significant with increasing degrees of obesity and thus, greater FM.

The disproportionate reduction in RMR in postobese individuals may reflect the genetic component of obesity. Once a defect in energy metabolism is established, it is important to identify the underlying mechanisms. Different mechanisms leading to obesity seem to be involved and emphazise the heterogeneous nature of obesity, for example, an altered responsiveness of the sympathoadrenal system, ${ }^{37}$ defects in substrate oxidation ${ }^{38}$ and lower levels of thyroid hormones. ${ }^{26}$ These mechanisms can cause a disproportionate reduction in RMR in post-obese individuals and, with that, a susceptibility to weight regain. Further research is necessary to investigate in depth the mechanisms responsible for the defects in energy metabolism.

\section{Conclusion}

The data of the present study demonstrate a normal SMR adjusted for body composition in the morbidly obese patients prior to VBG, while long-term weight loss after VBG results in a SMR which is significantly lower than expected, based on body composition. The sustained disproportionate reduction in SMR may explain the persistent susceptibility of the post-obese subjects to regain weight. As a consequence, the treatment of morbid obesity may only be successful when the therapeutic measures taken have a lifelong effect.

\section{References}

1 Ravussin E, Lillioja S, Knowler WC, Christin L, Freymond D, Abbott WGH, Boyce V, Howard BV, Bogardus C. Reduced rate of energy expenditure as a risk factor for body-weight gain. $N$ Eng $J$ Med 1988; 318: 467-472. 
2 Bogardus C, Lillioja S, Ravussin E, Abbott W, Zawadski JK, Young A, Knowler WC, Jacobowitz R, Moll PP. Familial dependence of the resting metabolic rate. $N$ Eng J Med 1986; 313: 96-100.

3 Keesey RE. Metabolic defense of body weight set-point. In: Stunkard AJ, Stellar E (eds). Eating and its disorders. Raven Press: New York, 1984, 87-95.

4 Kleiber M. The Fire of life. Krieger RE: New York, 1975.

5 Van Itallie TB. Morbid obesity. A hazardous disorder that resists conservative treatment. Am J Clin Nutr 1980; 33: 358363.

6 Garrow JS (ed). Treat obesity seriously. A clinical manual. Churchill Livingstone Inc: New York, 1981.

7 Saltzman E, Roberts SB. The role of energy expenditure in energy regulation: Findings from a decade of research. Nutr Rev 1995; 53: 209-220.

8 Renquist KE. Surgical treatment of obesity in America: Data according to the National Bariatric Surgery Registry. Probl Gen Surg 1992; 9: 231-238.

9 Deurenberg P, Weststrate JA, Seidell JC. Body mass index as a measure of body fatness: Age- and sex-specific prediction formulas. Br J Nutr 1991; 65: 105-114.

10 Schoeller DA, Van Santen E, Peterson DW, Dietz W, Jaspan J, Klein PD. Total body water measurement in humans with ${ }^{18} \mathrm{O}$ and ${ }^{2} \mathrm{H}$ labeled water. Am J Clin Nutr 1980; 33: 2686-2693.

11 Siri WE. Body composition from fluid spaces and density: Analysis of methods. In: Brožek J, Henschel A (eds). Techniques for measuring body composition. National Academy of Sciences: Washington DC, 1956, 239-280.

12 Schoffelen PFM, Westerterp KR, Saris WHM, Ten Hoor F. A dual-respiration chamber system with automated calibration. J Appl Physiol 1997 83: (In press).

13 Weir JB. New methods for calculating metabolic rate with special reference to protein metabolism. J Physiol 109: 1-9.

14 Westerterp KR, Donkers JHHLM, Fredrix EWHM, Boekhoudt P. Energy intake, physical activity and body weight: A simulation model. Br J Nutr 1995; 73: 337-347.

15 Elliot DL, Goldberg L, Kuehl KS, Bennett WM. Sustained depression of the metabolic rate after massive weight loss. $A m$ J Clin Nutr 1989; 49: 93-96.

16 Heshka S, Yang M, Wang J, Burt P, Pi-Sunyer FX. Weight loss and change in resting metabolic rate. Am J Clin Nutr 1990; 52: 981-986.

17 Geissler CA, Miller DS, Shah M. The daily metabolic rate of the post-obese and the lean. Am J Clin Nutr 1987; 45: 914 920.

18 Leibel RL, Rosenbaum M, Hirsch J. Changes in energy expenditure resulting from altered body weight. $N$ Eng $J$ Med 1995; 332: 621-628.

19 Buscemi S, Caimi G, Verga S. Resting metabolic rate and postabsorptive substrate oxidation in morbidly obese subjects before and after massive weight loss. Int J Obes 1996; 20: 4146.

20 Valtueña $\mathrm{S}$, Blanch $\mathrm{S}$, Barenys $\mathrm{M}$, Solà R, Salas-Salvadó J. Changes in body composition and resting energy expenditure after rapid weight loss: Is there an energy-metabolism adaptation in obese patients? Int J Obes 1995; 19: 119-125.

21 Racette SB, Schoeller DA, Kushner RF, Neil KM, Herlinglaffaldano K. Effects of aerobic exercise and dietary carbohydrate on energy expenditure and body composition during weight reduction in obese women. Am J Clin Nutr 1995; 61: 486- 494.

22 Froidevaux F, Schutz Y, Christin L, Jéquier E. Energy expenditure in obese women before and during weight loss, after refeeding, and in the weight-relapse period. Am J Clin Nutr 1993; 57: 35-42.

23 De Boer JO, Van Es AJH, Roovers LA, Van Raaij JMA, Hautvast JGAJ. Adaptation of energy metabolism of overweight women to low-energy intake, studied with whole-body calorimeters. Am J Clin Nutr 1986; 44: 585-595.

24 Lean MEJ, James WPT. Metabolic effects of isoenergetic nutrient exchange over 24 hours in relation to obesity in women. Int $J$ Obes 1988; 12: 15-27.

25 Astrup A, Buemann B, Toubro S, Ranneries C, Raben A: Low resting metabolic rate in subjects predisposed to obesity: A role for thyroid status. Am J Clin Nutr 1996; 63: 879-883.

26 Astrup A, Buemann B, Christensen NJ, Madsen J. 24-Hour energy expenditure and sympathetic activity in postobese women consuming a high-carbohydrate diet. Am J Physiol 1992; 262: E282-E288.

27 Amatruda JM, Statt MC, Welle SL. Total and resting energy expenditure in obese women reduced to ideal body weight. J Clin Invest 1993; 92: 1236-1242.

28 De Peuter R, Withers RT, Brinkman M, Tomas FM, Clark DG. No difference in rates of energy expenditure between postobese women and their matched, lean controls. Int $J$ Obes 1992; 16: 801-808.

29 Larson DE, Ferraro RT, Robertson DS, Ravussin E. Energy metabolism in weight-stable postobese individuals. Am J Clin Nutr 1995; 62: 735-739.

30 Wadden TA, Foster GD, Letizia KA, Mullen JL. Long-term effects of dieting on resting metabolic rate in obese outpatients. JAMA 1990; 264: 707-711.

31 Buemann B, Astrup A, Madsen J, Christensen NJ. A 24-h energy expenditure study on reduced-obese and nonobese women: Effect of $\beta$-blockade. Am J Clin Nutr 1992; 56: 662-670.

32 Nelson KM, Weinsier RL, James LD, Darnell B, Hunter G, Long CL. Effect of weight reduction on resting energy expenditure, substrate utilization, and the thermic effect of food in moderately obese women. Am J Clin Nutr 1992; 55: 924-933.

33 Ravussin E, Burnand B, Schutz Y, Jéquier E. Twenty-fourhour energy expenditure and resting metabolic rate in obese, moderately obese, and control subjects. Am J Clin Nutr 1982; 35: 566-573.

34 Astrup A. Obesity and metabolic efficiency. Ciba Foundation Symposium 1996; 201: 159-173.

35 Hoffmans M, Pfeifer WA, Gundlach BL, Nijkrake HGM, Oude Ophuis AJM, Hautvast JGAJ. Resting metabolic rate in obese and normal weight women. Int J Obes 1979; 3: 111118.

36 Astrup A, Andersen T, Christensen NJ: Impaired glucoseinduced thermogenesis and arterial norepinephrine response persist after weight reduction in obese humans. Am J Clin Nutr 1990; 51: 331-337.

37 Astrup A, Buemann B, Toubro S, Raben A: Defects in substrate oxidation involved in the predisposition to obesity. Proc Nutr Soc 1996; 55: 817-828. 